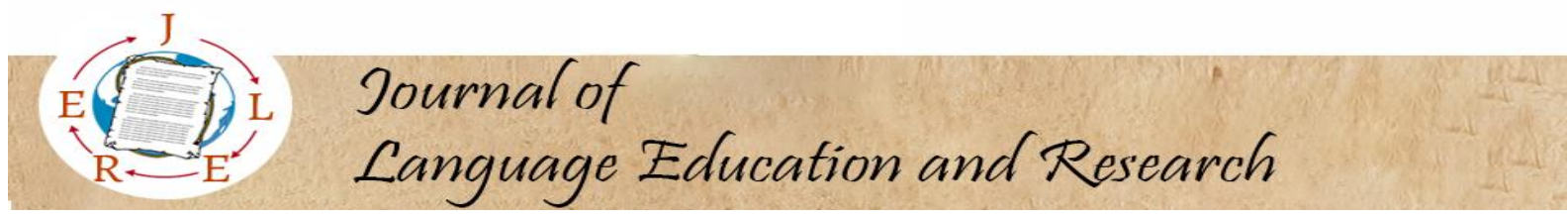

$7(1), 2021$

Journal of Language Education and Research

\author{
Research Article
}

\title{
Using Edmodo as a Social Platform to teach EFL Writing for Preparatory School Students
}

\begin{tabular}{l}
\hline ARTICLE INFO \\
\hline Received 30.12.2020 \\
Revised form 19.02.20 \\
Accepted 02.03.2021 \\
Doi: 10.31464/jlere.85079 \\
\\
Keywords: \\
Collaborative Writing \\
Social Constructivism \\
Edmodo \\
e-portfolio \\
Google Docs
\end{tabular}

\section{ARTICLE INFO}

Received 30.12.2020

Accepted 02.03.2021

Google Docs

\section{Keywords:}

Edmodo

\author{
Turan Paker * $\quad$ Nurgül Doğan $^{* *}$
}

\begin{abstract}
This study aimed to identify the perceptions of preparatory school students studying in the School of Foreign Languages in a state university towards using Edmodo to improve their writing skill in English. The participants were 52 students who used Edmodo together with Google Docs collaboratively and interactively for their nine collaborative and individual writing tasks. Besides, the teacher has uploaded some course materials onto Edmodo to support their learning process. The students have studied various EFL writing tasks for one semester through Edmodo. In order to collect the data, convergent parallel design of mixed design was adopted. Quantitative and qualitative data were collected and analysed separately, then they were classified and interpreted together. The results revealed that the participants highly favoured using Edmodo for their writing classes and found it very useful and enjoyable, and they also pointed out that using Edmodo interactively helped them develop their writing skill. In addition, they highly appreciated the e-portfolio function of Edmodo since it has provided easy access to their previous tasks and related feedback.
\end{abstract}

Statement of Publication Ethics

Authors' Contribution Rate

Conflict of Interest
The study has been conducted by following the publication ethics. We confirm that the study does not need ethics committee approval according to the research integrity rules in the country.

The manuscript was collaboratively composed from beginning to the end by the two authors.

We do not have any conflict of interest.

\footnotetext{
* Prof. Dr., ORCID ID: https://orcid.org/0000-0002-3941-3975, Pamukkale University, Faculty of Education, Department of Foreign Languages Education, English Language Teaching Unit, tpaker@gmail.com

** Instructor, ORCID ID: https://orcid.org/0000-0001-5707-8990, Uşak University, School of Foreign Languages, nurgul.dogan@usak.edu.tr

*** This article was produced from the MA thesis, titled "Collaborative social learning: using Edmodo as a social platform to teach EFL writing for preparatory school students," conducted in The Institute of Educational Sciences, Pamukkale University, Turkey.
} 


\section{Introduction}

Learning writing in second language learning (L2) is different from learning the other skills because it requires some competences such as outlining, organizing your opinions in cohesion, knowledge of paragraph or text organization and genres of texts, etc. Writing in L2 requires using metacognitive skills (Klimova, 2014). Students should be knowledgeable in delivering the content in an organization, appropriate vocabulary usage and language use and also mechanics (Olshtain, 2000). Brown and Lee (2015) ask the crucial question: 'Why do not people learn to write 'naturally,' as they learn to talk? How can we best teach L2 learners how to write?" (p. 426). This question was the starting point of the study. In our case, writing in L2 is perceived as a less communicative and interactive language skill in the classroom setting in the preparatory program because there is not usually a real audience for most of the writing tasks suggested by the text books and the school program but only some topics to respond to. The interaction takes place only between the teacher and the students, which contradicts Vygotskian way of learning, which stresses the idea that learning occurs within the social activities where learners interact (Stacey, 1999). Furthermore, most of the time the students write not to convey a message for real communication purposes, but just to fulfil a task or copy a model, and most importantly, the students write to get a passing grade in the examinations. According to Brown and Lee, (2015), students' written products are not authentic. In addition, students cannot get necessary feedback from their teachers, which does not lead to process writing dealing with a couple of drafts and ends up with a final version (Raimes, 1983). As writing is a process, the writing skill should be carried out in a process writing framework (Raimes, 1983). In this framework, students write for real audiences with real purposes, which results in ownership of students towards their writing, and they collaborate with each other through the supportive efforts of the teacher (Graham \& Sandmel, 2011). Hence, the main problem with teaching writing skill in our case is that writing skill is taught traditionally by means of pen-and-paper based instruction, with non-authentic tasks, in non-interactive settings by ignoring students' computer literacy. In addition, traditional writing instruction is usually limited only to the classroom in terms of interaction time and place. There are also physical conditions to be considered with traditional interactive writing tasks such as sitting arrangement and noise. With group works of 4-5 members, all members cannot see what is written on the collaborative paper, and everyone in the group cannot edit the work, only pair work is possible. Besides, there are some classroom management and especially noise problems as well.

On the other hand, nowadays, the students have high information and communication technology literacy (ICT) and interests as they were born to a digital world. Then, as they were "digital natives" (Prensky 2001), trying to teach writing traditionally may not motivate them as expected. ICT literacy can be defined as "an individual's ability to use computers to investigate, create and communicate in order to participate effectively at home, at school, in the workplace and in society". (OECD, 2013) Based on their one way communicative, pen and pencil type classroom writing, it would be natural to assume that students may have difficulties in surviving digital platforms with their future writing tasks in real life within this high technological era. According to 
OECD report (2015), students who are unable to navigate through a complex digital landscape will no longer be able to participate fully in the economic, social and cultural life around them. With the development of web 2.00 technologies, educators and researchers have turned their attention to the use of these tools in terms of collaborative, interactive and social learning in language education (Karpati, 2009). "Since designing technology-enhanced language classes is a new approach in the field of language education in Turkey, many aspects of using Web 2.0 technologies in language classes still need to be investigated" (Ciftci \& Kocaoglu, 2012, p. 62). Therefore, we believe that by integrating a Web 2.00 tool -Edmodo- into writing course, the students can cooperate and collaborate by interacting with the teacher and their peers, and also satisfy their technological interest both in and out of the classroom setting. Edmodo is known as an educational website platform for teachers and students for connection, interaction and collaboration both in and outside the classroom (Trust, 2017; Tsiakyroudi, 2018).

\section{Literature review}

Theoretically, the present study as in some studies in which a Web 2.00 tool was used for collaboration hypothesize the social construction of knowledge and discuss and explain how it is possible to construct knowledge collaboratively in a social environment through a tool as well as the students' perceptions. According to Vygotsky (1978), learning is a phenomenon that happens in society rather than being individual. Three concepts stand out under this theory: social interaction, the more knowledgeable other (MKO) and the zone of proximal development (ZPD). Social interactions play important roles in children's cognitive development. The more knowledgeable other (MKO) refers to the one who has more skills than the learner. Therefore, MKO supports the novice to construct knowledge as a result of interaction. "Such assistance is now commonly referred to in the literature as scaffolding" (Storch, 2005, p.154). Zone of the proximal development (ZPD) refers to the place where a child can construct the knowledge by collaborating with a peer or interact with teacher. Learning occurs by mediating and scaffolding with more knowledgeable other. When the studies in the literature are reviewed in terms of constructivism, it is seen that this theory constitutes a foundation stone in language education. Social constructivism (Vygotsky, 1978) was considered as the basis for methodology used in the present study because Edmodo creates social constructivist environment both in and out of the classroom.

As for the collaborative writing via Web 2.00 tools, Elola and Oskoz (2010) structured their research on social terms of language learning, and they got students' positive reactions towards using wikis for ESL writing. Similarly, Wu and Wu (2011) explained the students' positive thoughts of using blogs where they interactively carried out. Likewise, Storch (2005) claims, in his experimental study, the participants write better collaboratively than individually. Although Seyyedrezaie et al. (2016) got the students' negative reactions of using Google Docs for collaboration for various reasons, Woodrich and Fan (2017) stated that using Google Docs may open a door for non-attentive students based on their positive reactions despite no evidence of better-quality works of collaborative tasks than individual tasks. Similarly, Kongchan (2013) investigated 
students' and a teacher's perceptions of using Google Docs and Edmodo collaboratively. He also stated how using Edmodo, and Google Docs made it possible to give real time feedback. Edmodo gives its users an opportunity to combine Google Docs. Teachers or students can link a Google Doc to a post. While submitting their assignments the students can reach their GoogleDrive folders or directly their Google Docs thanks to the uploading features of Edmodo.

On the other hand, Pop (2013) focused on the e-portfolio function of Edmodo. Purnawarman et al. (2016) studied Edmodo for EFL writing, and their findings supported the social norms of learning in that the students indicated that Edmodo enabled them to join peer groups and interact with each other. Correspondingly, Kayacan and Razı (2017) focused on self and peer feedback via Edmodo in their quasi-experimental study. The results showed that self and peer feedback provided improvement in students' writings. Besides, the researchers got positive perceptions of the students towards using Edmodo for their ESL writings. Parallel to this study, Hamutoğlu and Kıyıc1 (2017) indicated the participants' positive reactions towards using Edmodo. Additionally, Manowong (2016) studied EFL learners' perceptions about Edmodo, and the researcher explained that the learners perceived Edmodo as a useful supplementary tool.

In this study, Edmodo and Google Docs were used collaboratively and interactively for EFL writing classes in the context of School of Foreign Languages in Uşak university. The aim of this study is to identify students' perceptions about effectiveness of using a Web 2.0 tool, Edmodo, as a social and collaborative platform in developing their writing skill. For this purpose, the present study focuses on the following research questions:

1. What are opinions of the preparatory students about using Edmodo in EFL writing classes?

a. Does using Edmodo interactively develop their writing skill?

b. Is Edmodo an effective social platform which can promote social interaction for them while writing in English?

\section{Methodology}

\section{Research design}

In this study, a convergent parallel design of mixed research type was used to triangulate the quantitative data with qualitative data (Creswell and Plano Clark, 2011) and to enhance the process-based study by various data. Thus, the quantitative data and qualitative data were collected and analysed separately, then as a second step, they were related and finally, they were interpreted together in terms of research questions. As a quantitative method a Likert type questionnaire was administered. The questionnaire was composed of 40 items. Some items were developed based on the content analysis of the paragraphs previously assigned to students, and the rest of the items were adapted from Manowong (2016). A semi-structured interview was carried out in order collect data qualitatively. 


\section{Context}

The study was conducted in the School of Foreign Languages, voluntary English preparatory program in Uşak University. The study was particularly conducted in this context where students study English intensively to be proficient at B1+ level so that they can attend their academic studies in their departments. Thus, students attend the English preparatory program for an academic year for two semesters in which they study four language skills.

\section{Participants}

The participants were 52 EFL students, aged between 17-21. They were 24 males and 28 females. The proficiency level of the students was A2, which was identified in the placement test given at the very beginning of the semester. They were grouped randomly in accordance with their proficiency level. The participants had 25 hours of English classes per week throughout the semester. The study included 10 hours of Reading and Writing Course per week, and the participants completed nine writing tasks via Edmodo through one semester. The participants, first of all, were informed that they were going to use Edmodo for a virtual writing class throughout the semester. They were assigned to set up a Gmail address to use it for Edmodo enrolment, Google Docs and Google Drive in the first lesson. In addition, Edmodo with its all features was introduced to participants in all groups. They were also informed on how to use Google Docs with multiple authors.

\section{Data collection and analysis}

Having completed the writing tasks, stated in the procedure subsection, the data were collected through a 5-point Likert-scale type questionnaire composed of 40 items and a semi-structured interview composed of four open ended questions. The participants were asked to sign volunteer informed/consent form. Upon using Edmodo for a semester, the participants were asked to write a paragraph about their experience on Edmodo. Based on the content analysis of the students' paragraphs some themes were detected. As a final stage, items for the questionnaire were developed. Besides, some items were adapted from Manowong (2016). Next, opinions of three experts working in the ELT department were consulted. According to experts' views about technical issues and the content, the questionnaire was rearranged and was prepared to be ready to be applied. The questionnaire included following options for each item: strongly disagree $=1$, disagree $=2$, partially agree $=3$, agree $=4$ and strongly agree $=5$. Statistical data were analysed descriptively by using SPSS 23 software program. A rating guide was adopted from Manowong (2016). Accordingly, the students' responses to the survey were categorized as 4.21-5= strongly agree, 3.41-4.2=agree, 2.61-3.4= partially agree, 1.81-2.6=disagree, and $1-1.8=$ strongly disagree. To be able to draw meaningful results from the quantitative data, the items on the questionnaire were matched with the research questions and interpreted in accordance with the research question. Besides, the quantitative data were related by the qualitative results collected from contents analysis of the students' answers to the following semi structured interview questions: 
1. What are your general opinions about using Edmodo for writing classes?

2. Did using Edmodo interactively such as group works or working with your classmates and your teacher on the same Google Doc at the same time contribute to improving your writing skill? If yes, how did it contribute to improve your writing skill?

3. Did using Edmodo interactively help you learn from each other and your teacher? If yes, how?

4. How do you evaluate Edmodo as an application in terms of reaching your course materials, assignments and your grades any time?

Upon analysing data obtained from the responses to the questionnaire and semistructured interviews, the quantitative results were presented on tables including mean value $(M)$, standard deviation $(S D)$, percentages for the level of agreement (\%). Qualitative data results were also presented in terms of triangulation of two types of data. Each research question was used as a basis for presentation and interpretation of the results.

\section{Procedure}

The instructor introduced the procedure of how to use Edmodo as a first step. Then, in order to deal with them effectively in terms of pair and group feedback, she divided them into three different groups, and shared the class codes with the students. Nine writing tasks were carried out via Edmodo during the semester. The students used Google Docs as sheets for their tasks. Five individual writing tasks and four collaborative writing tasks were covered during the study. Task 1, task 2, task 6, task 7 and task 9 included writing paragraphs individually. For those individual tasks, the interaction was among the students who wrote the task and the instructor. For writing task 6 , however, the interaction was among the students through peer-feedback. Task 3, task 4, task 5 and task 8 included collaborative writing. The students followed the procedures in accordance with the OCL (online collaborative learning) theory suggested by Harasim (2012). First, the students brainstormed, then, they discussed the ideas in brainstorming part and eliminated some ideas, and finally, they produced tasks collaboratively. The interaction for the collaborative works in the study was between the students-teacher and among the students. Task 1, task 2 , task 3 , task 4 , and task 5 were narrative paragraphs, and they were mainly written in a free task in terms of their organization. Task 6 included writing a descriptive paragraph. Task 7, task 8 and task 9 included writing expository paragraphs for which students provided a topic statement, supporting statements/ideas and a concluding statement. For each writing task, the students received instruction, and the teacher also modelled the task when needed. The students got real-time feedback for their writing. For the second drafts of their tasks, they got feedback both for content and language of their tasks.

\section{Results}

The findings as a result of data analysis have been presented in terms of research questions. The first research question was "What are students' opinions about using 
Edmodo?" Item 33, 14, 22, 19, 8, 26, 32, 23, 5, 17, 6, 7, 30 and 16 were assigned to research question 1 (Table 1). The quantitative results of these items and overall mean value and the qualitative results obtained from students' responses to the interview questions were presented and interpreted. Table 1 shows the results in terms of means and percentages in a descending order.

Table 1. Students' perceptions about using Edmodo

$\mathrm{N}=52$

\begin{tabular}{|c|c|c|c|c|c|c|c|}
\hline Item Description & $\mathbf{M}$ & SD & SD\% & D\% & PA\% & A\% & SA\% \\
\hline $\begin{array}{l}\text { 33. Edmodo provided a good virtual } \\
\text { writing platform where I could interact } \\
\text { with my friends and teacher at any time. }\end{array}$ & 4.21 & 0.89 & 1.9 & 3.8 & 7.7 & 44.2 & 42.3 \\
\hline 14. I am happy with Edmodo. & 4.05 & 1.05 & 5.8 & 0 & 17.3 & 36.5 & 40.4 \\
\hline $\begin{array}{l}\text { 22. Writing activities became more fun } \\
\text { thanks to Edmodo. }\end{array}$ & 4.01 & 1.12 & 5.8 & 5.8 & 9.6 & 38.5 & 40.4 \\
\hline $\begin{array}{l}\text { 19. Thanks to Edmodo, what I wrote was } \\
\text { permanent and I could check my language } \\
\text { mistakes when I wanted. }\end{array}$ & 3.98 & 1.09 & 3.8 & 5.8 & 19.2 & 30.8 & 40.4 \\
\hline $\begin{array}{l}\text { 8. Edmodo was helpful in improving my } \\
\text { writing skill. }\end{array}$ & 3.92 & 0.98 & 3.8 & 1.9 & 23.1 & 40.4 & 0.8 \\
\hline $\begin{array}{l}\text { 26. That more than one person was able to } \\
\text { work on and correct mistakes on the same } \\
\text { page in Google Docs collaborative writing } \\
\text { tasks contributed to my learning of writing. }\end{array}$ & 3.90 & 1.03 & 3.8 & 3.8 & 23.1 & 36.5 & 32.7 \\
\hline $\begin{array}{l}\text { 32. The writing activities we did by using } \\
\text { Google Docs were more useful than the } \\
\text { ones we did individually by using pen and } \\
\text { pencil. }\end{array}$ & 3.90 & 0.99 & 1.9 & 7.7 & 19.2 & 40.4 & 30.8 \\
\hline $\begin{array}{l}\text { 23. Thanks to Edmodo I was able to } \\
\text { follow the lessons outside the school. }\end{array}$ & 3.69 & 1.09 & 5.8 & 7.7 & 21.2 & 42.3 & 23.1 \\
\hline $\begin{array}{l}\text { 5. Online activities such as exams, } \\
\text { assignments and discussions in Edmodo } \\
\text { were time consuming. }\end{array}$ & 2.46 & 1.17 & 23.1 & 34.6 & 21.2 & 15.4 & 5.8 \\
\hline $\begin{array}{l}\text { 17. The use of Edmodo required extra } \\
\text { time and effort. }\end{array}$ & 2.38 & 1.03 & 21.2 & 34.6 & 32.7 & 7.7 & 3.8 \\
\hline $\begin{array}{l}\text { 6. Since I do not have constant internet } \\
\text { access I am deprived of my homework and } \\
\text { writing activities. }\end{array}$ & 2.25 & 1.20 & 28.8 & 40.4 & 17.3 & 3.8 & 9.6 \\
\hline $\begin{array}{l}\text { 7. It was difficult to follow the procedures } \\
\text { in Edmodo (sending homework, linking, } \\
\text { etc.) }\end{array}$ & 2.17 & 1.18 & 34.6 & 32.7 & 21.2 & 3.8 & 7.7 \\
\hline $\begin{array}{l}\text { 30. I was disturbed by the observation of } \\
\text { the teacher and my classmates on my } \\
\text { writing process in group works we did by } \\
\text { using Google Docs. }\end{array}$ & 1.88 & 1.04 & 42.3 & 40.4 & 7.7 & 5.8 & 3.8 \\
\hline
\end{tabular}




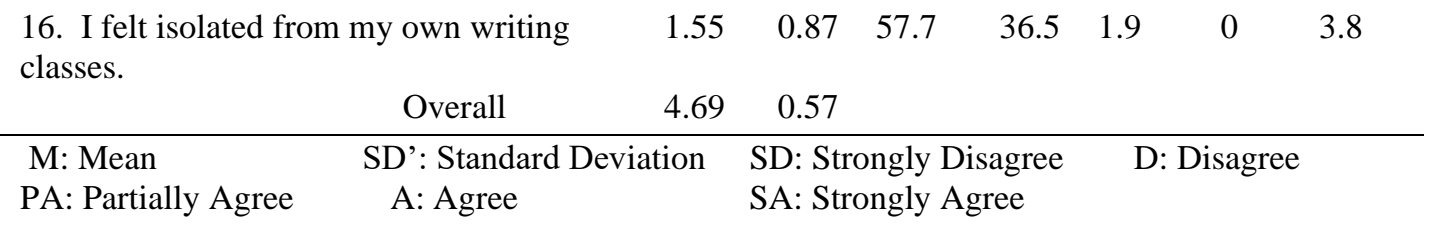

When the findings regarding the students' general opinions about using Edmodo were analysed, the overall mean value was 4.69 , which meant the students had quite positive reactions towards using Edmodo for ESL writing classes. The responses given to Q1 supported this quantitative data as in the following:

Using Edmodo for writing classes was really helpful in general terms (Interview records, S4).

I had a chance to practice on technologies on modern world by using such an application as Edmodo for writing classes. So, I think the writing activities via Edmodo is helpful (Interview Records, S1).

I have met Edmodo for writing classes for the first time... I can say that it is a very useful application. We have benefitted the easiness of communication with our teacher and classmates (Interview Records, S7).

... Edmodo was fun when studying writing with my friends (Interview Records, S1).

Items 33, 14, 22, 19, 8, 26, 32, and 23 included positive statements about Edmodo (Table 1). The students indicated that Edmodo provided a good virtual writing platform where they could interact with their friends and the teacher at any time (M: 4.21;SD:0.89). Next, the students agreed that they were happy with Edmodo ( $M: 4.05 ; S D: 1.05)$. In addition, the responses of the students indicated that writing activities became more fun thanks to Edmodo ( $M: 4.01 ; S D: 1.12)$. Besides, the students agreed that what they wrote was permanent, and they could check their language mistakes whenever they wanted thanks to Edmodo (M: 3.98; SD: 1.09). Next, the students believed that Edmodo was effective in improving their writing skill ( $M: 3.92 ; S D$ : 0.98 ). The following response to Q1 supported this quantitative data for item 8 , in which the students agreed that Edmodo was helpful in improving their writing skill (Table 1):

Thanks to Edmodo, I think my writing skill has improved (Interview Records, S5).

Furthermore, the following response supported item 19 in which students stated that thanks to Edmodo, what they wrote was permanent and they could check their language mistakes whenever they wanted.

What I wrote became permanent thanks to Edmodo (Interview Records, S5)

Item 8 in which the students thought Edmodo helped improve their writing skill was also in parallel with the following response to Q1:

Edmodo, which we use for writing classes ..., is a social network which is very helpful for our writing tasks (Interview Records, S6). 
In addition, the students agreed that multiple authoring in collaborative writing tasks via Edmodo contributed to developing their writing skill ( $M: 3.90 ; S D: 1.03)$.

Moreover, the students preferred collaborative writing tasks rather than individual pen-and-pencil writing tasks because they thought collaborative writing tasks were effective ( $M: 3.90 ; S D: 0.99)$. Next, the students favoured the fact that they could follow lessons outside the classroom thanks to Edmodo ( $M: 3.69 ; S D: 1.09$ ). Items 5, 17, 6, 7, 30, and 16 included reversed statements about Edmodo.

On the other hand, the students disagreed that using Edmodo was time consuming ( $M: 2.46 ; S D: 1.17)$. A high majority of the students disagreed the idea that Edmodo was an extra burden for writing classes ( $M: 2.38 ; S D: 1.03)$. Additionally, most of the students seemed to have internet access outside the classroom and could follow the writing lessons via Edmodo because majority of the students disagreed that they were deprived of writing lessons via Edmodo ( $M: 2.25 ; S D: 1.20)$. Next, the students disagreed that it was difficult to use Edmodo ( $M: 2.17 ; S D: 1.18$ ). The students seemed not disturbed to work on groups on Google Docs, and they agreed that they were tolerant to be observed by the teacher while writing on a Google Doc ( $M: 1.88 ; S D: 1.04)$. Additionally, almost all the students did not feel isolated from their own writing classes $(M: 1.55 ; S D: 0.87)$ (Table 1).

The sub-research question was "Does using Edmodo interactively develop students' writing skill?" Items 31, 34, 8, 21, 18 and 36 were assigned to research question 2 (Table 2) and the quantitative results of these items, and overall mean value were supported by the qualitative results obtained from students' responses to the interview questions. Table 2 shows the results of qualitative data related to the second research question in a descending order.

Table 2. Using Edmodo Interactively in Developing Writing Skill.

$\mathrm{N}=52$

\begin{tabular}{|c|c|c|c|c|c|c|c|}
\hline Item Description & $\mathrm{M}$ & SD' & $\mathrm{SD} \%$ & $\mathrm{D} \%$ & PA\% & $\mathrm{A} \%$ & SA\% \\
\hline $\begin{array}{l}\text { 31. That the teacher was able to control all } \\
\text { the computers at the same time and that she } \\
\text { gave immediate feedback have contributed } \\
\text { improving my writing skill. }\end{array}$ & 4.11 & 0.96 & 3.8 & 1.9 & 11.5 & 44.2 & 38.5 \\
\hline $\begin{array}{l}\text { 34. In Edmodo's interactive writing tasks I } \\
\text { learned both from my friends and my } \\
\text { teacher about writing skill. }\end{array}$ & 4.05 & 0.93 & 1.9 & 5.8 & 11.5 & 46.2 & 34.6 \\
\hline $\begin{array}{l}\text { 8. Edmodo was helpful in improving my } \\
\text { writing skill. }\end{array}$ & 3.92 & 0.98 & 3.8 & 1.9 & 23.1 & 40.4 & 30.8 \\
\hline $\begin{array}{l}\text { 21. I think my writing skill has improved } \\
\text { thanks to the writing activities we have } \\
\text { done with the group. }\end{array}$ & 3.90 & 1.05 & 3.8 & 5.8 & 19.2 & 38.5 & 32.7 \\
\hline $\begin{array}{l}\text { 18. Thanks to Edmodo I could create a } \\
\text { writing folder and compare my language } \\
\text { level of proficiency at the end of the } \\
\text { semester with my language level of } \\
\text { proficiency at the beginning of the } \\
\text { semester. }\end{array}$ & 3.75 & 1.06 & 3.8 & 5.8 & 30.8 & 30.8 & 28.8 \\
\hline
\end{tabular}


36. The use of Edmodo in writing lessons $\quad \begin{array}{lllllll}1.80 & 1.02 & 48.1 & 34.6 & 9.6 & 3.8 & 3.8\end{array}$ did not affect the development of my writing skill.

The overall mean value was 4.00 with a 0.87 standard deviation for this section, which meant the students believed that their writing skill developed by using Edmodo interactively. The following responses to Q2 and Q3 supported the mean value for this section:

Thanks to Edmodo, we both worked better as a group and our writing skill improved. We got used to computers in doing our tasks, and our writing skill improved (Interview Records, S2).

Edmodo allowed me to easily interact with my friends and teacher. What I wrote in Google Docs was permanent, and I was able to enter and edit my text whenever I wanted. I think my writing skill improved thanks to Edmodo (Interview Records, S5).

Our teacher warned us to make the necessary arrangements since our teacher had control over the document. Thus, what we wrote was getting better (Interview Records, S7).

Items 31, 14, 8, 21, and 18 included positive statements about Edmodo (Table 2). The students indicated that the teacher was able to control all the computers at the same time, and she gave regular feedback, which contributed to improving their writing skill ( $M$ : 4.11; SD: 0.96). The following response to Q2 supported this quantitative result for the item 31 in which students thought that the teacher was able to control all the computers at the same time and that she gave immediate feedback, which contributed to improve their writing skill (Table 2):

The fact that I was able to use Edmodo (Google Docs) at the same time with my teacher and classmates contributed to correct my mistakes and made them permanent. ... And our teacher was able to correct the mistakes immediately (Interview Records, S2).

In addition, the students believed that thanks to interactive writing tasks, they learned from their friends and the teacher ( $M: 4.05 ; S D: 0.93)$. This quantitative result was supported by the responses to Q2 as in the following:

Of course, it helped our writing skill improve. We observed each other's assignments and learnt a lot of vocabulary. Our group work improved not only our writing but also reading skill (Interview Records, S3).

In addition, the students believed that Edmodo helped them improve their writing skill ( $M$ : 3.92; $S D$ : 0.98). Next, the students agreed that their writing skill improved thanks to writing activities carried out in the group $(M: 3.90 ; S D: 1.05)$. The following response to Q2 supported this quantitative result for the item 21 in which the students thought their writing skill improved thanks to the writing activities they did with the group:

Using Edmodo interactively in writing lessons enabled me to be interactive with my friends and teacher. Using Google Docs enabled me to see the mistakes of both my friends and myself. I think my writing skill has improved better in group writing classes (Interview Records, S5)

Next, the following qualitative results obtained from Q1 and Q2 supported the quantitative results $(M: 3.92 ; S D: 0.98)$ of item 8 in which the students agreed that their writing skill has improved thanks to using Edmodo:

In the writing course, I had the opportunity to practice on the necessary technologies both in the class and out of the class in the modern world using an application such as Edmodo.

That's why, I think writing activities are useful in Edmodo (Interview Records, S1). 
It is a very useful application in terms of seeing our grammar mistakes, and when we use Google Docs simultaneously, it is a useful application to correct and learn the mistakes of our friends, and to see and correct our own mistakes, too (Interview Records, S4).

Finally, the students indicated that they created a writing folder, thanks to which they were able to compare their language level and writing skill with the ones in the beginning of the course $(M: 3.75 ; S D: 1.06)$. Item 36 included a reversed statement questioning whether the use of Edmodo in writing lessons affects the development of their writing skill (Table 2). The mean score (1.80) and standard deviation (1.02) indicated that the students believed that the use of Edmodo in writing lessons affected the development of their writing skill to a great extent (Table 2).

The second sub-research question was "Is Edmodo an effective social platform which can promote social interaction for students while writing in English?" Items 2, 33, $35,1,12,11,15,10,24,23,37$ and 39 were assigned to research question 3 (Table 3). The quantitative results of these items, and overall mean value were supported by the qualitative results obtained from students' answers that they gave to the interview questions. Table 3 shows the results of the qualitative data related to the third research question.

Table 3. Edmodo as an effective social platform which promotes social interaction while writing in

English.

Item Description
2. Edmodo is suitable for writing, sending
homework and doing other activities for
learning foreign languages.
33. Edmodo provided a good virtual
writing platform where I could interact
with my friends and teacher at any time.

35. Edmodo made it easy for me to participate in classroom activities with my classmates and teachers about assignments, group tasks and other lesson activities.

1. Edmodo made it easy for me to $4.21 \quad 0.8$ 0.891 .9

3
$0.90 \quad 3.8$

$(0$

$9.6 \quad 48.1 \quad 38.5$
communicate and interact with classmates and the teacher about assignments, group assignments, and other lesson activities.

12. I think that when we used Edmodo, my interaction with the instructor increased.

11. Thanks to Edmodo, I made homework, group tasks and other lesson activities, and thus I increased interaction with other students.

15. Thanks to Edmodo I felt myself connected with the class and the teacher.

10. Asking questions to my teacher and classmates through Edmodo helped me

$\begin{array}{lllllll}4.03 & 1.13 & 5.8 & 3.8 & 15.4 & 30.8 & 44.2\end{array}$

$\begin{array}{lllllll}3.98 & 1.07 & 3.8 & 5.8 & 17.3 & 34.6 & 38.5\end{array}$

$\begin{array}{lllllll}3.96 & 1.02 & 3.8 & 5.8 & 13.5 & 44.2 & 32.7\end{array}$

$\begin{array}{lllllll}3.90 & 1.07 & 3.8 & 5.8 & 21.2 & 34.6 & 34.6\end{array}$


write more effectively.

\begin{tabular}{|c|c|c|c|c|c|c|c|}
\hline $\begin{array}{l}\text { 24. I could easily exchange ideas with my } \\
\text { friends in writing tasks. }\end{array}$ & 3.80 & 1.17 & 7.7 & 5.8 & 15.4 & 40.4 & 30.8 \\
\hline $\begin{array}{l}\text { 23. Thanks to Edmodo I was able to } \\
\text { follow the lessons outside the school. }\end{array}$ & 3.69 & 1.09 & 5.8 & 7.7 & 21.2 & 42.3 & 23.1 \\
\hline $\begin{array}{l}\text { 37. Edmodo did not help me } \\
\text { communicate with my friends during the } \\
\text { writing lessons. }\end{array}$ & 1.75 & 1.06 & 51.9 & 34.6 & 5.8 & 1.9 & 5.8 \\
\hline $\begin{array}{l}\text { 39. Edmodo was not an effective tool for } \\
\text { writing lessons. }\end{array}$ & 1.69 & 1.00 & 51.9 & 38.5 & 3.8 & 0 & 5.8 \\
\hline Overall & 4.06 & 0.87 & & & & & \\
\hline
\end{tabular}

The overall mean value was 4.06 with a 0.87 standard deviation for this section, which means that the students believed that Edmodo was an effective social platform which promoted social interaction while writing. The following responses to Q1 and Q3 during interviews supported the mean value for this section:

I have used Edmodo for the first time. I can say that it is a very useful application. Ease of communication with our teacher and friends has helped us a lot (Interview Records, S7).

I have learned Edmodo for the first time in the preparatory class, and we have used it a lot. I think it is very useful because all of us and the teacher can use it together and exchange information (Interview Records, S3).

During our work with Google Docs, we learned the things we never knew or misunderstood the things while listening to the teacher, and we learned the things from each other from time to time; therefore, we learned the best, and this enabled us to write effectively (Interview Records, S6).

Items $2,33,35,1,12,11,15,10,24$, and 23 included positive statements about Edmodo (Table 1). The students agreed that Edmodo was suitable for writing, sending and doing other activities in English ( $M: 4.30 ; S D: 1.03)$. The following responses to Q4 supported the quantitative data for the item 2:

I can reach all the information thanks to Edmodo. I have not experienced any problems so far. It is a really useful application. I liked it, too (Interview Records, S3)

Thanks to the homework files I have created in Edmodo, it is an easy and safe application in terms of use where I can compare my first work with my last work and learn my scores easily (Interview Records, S6)

In addition, the students approved Edmodo as a good learning platform where they could interact with their friends and the teacher any time $(M: 4.21 ; S D: 0.89)$. The mean score of item 35 (4.17) and standard deviation (0.90) indicated that the students held positive beliefs about Edmodo which facilitates participation in classroom activities with peers and the teacher about assignments, groups tasks and other lesson activities. In addition to participation, the students also believed that Edmodo provided them with communication and interaction with their classmates and the teacher about their assignments, group assignments, and other lesson activities ( $M: 4.09 ; S D: 1.14)$. The following responses Q1 and Q3 represents the idea of all group: 
I have used Edmodo for the first time... I think it is really useful. I think it is useful in that we use it as a whole class and together with our teacher, and we can exchange our ideas (Interview Records, S3).

Using Edmodo and Google Docs as a group, we both have seen our own mistakes and learned from our friends' mistakes. I think it has speeded up our learning this way (Interview Records, S1).

Next, the students believed that they had more interaction with their teacher when they used Edmodo ( $M: 4.03 ; S D: 1.13)$. The students indicated that they carried out homework and other class activities via Edmodo, and by doing this, they believed they increased their interaction with the classmates (M: 3.98; SD: 1.07). Moreover, the students felt that they were easily connected to the teacher and the classmates thanks to Edmodo (M: 3.96; $S D$ : 1.02). The following quotations obtained from Q2 and Q3 support this item as well:

Edmodo has provided me an easy interaction with my teacher and classmates (Interview Records, S5)

We have used Edmodo frequently because our assignments have been given over Edmodo for a year. We have had group works and individual works. Thus, we have learned a lot both from each other and from our teacher (Interview Records, S3).

On the other hand, the mean value of item 10 (3.90 and $S D$ : 1.07) indicated students' positive perceptions towards the effectiveness of discussions with the classmates and the teacher carried out either on Edmodo or Google Docs. Next, the students indicated that they could easily exchange their ideas with their classmates while writing ( $M: 3.80$; $S D$ : 1.17). The students also indicated that they could follow the lessons outside the classroom, which meant they could even interact and learn outside the classroom (M: 3.69; $S D$ : 1.09). The students pointed out their ideas on this issue within $\mathrm{Q} 4$ as follows:

I can follow the previous lesson or the lesson that I hadn't attended by getting the course materials any time on Edmodo (Interview Records, S1).

It was very useful in terms of having an access to our works any time because they are recorded and kept somewhere. Occasionally, I enter Edmodo and check my work (Interview Records, S7).

Being able to reach Edmodo at any time was a great advantage for students because we always remembered the work, we did them by entering Edmodo whenever we wanted (Interview Records, S2).

Items 37 and 39 included reversed statements about Edmodo (Table 3). The students rejected the statements that Edmodo was not useful to interact with their classmates $(M: 1.75 ; S D: 1.06)$. Furthermore, the students strongly disagreed with the statement that Edmodo was not easy to use for writing lessons ( $M: 1.69 ; S D: 1.00)$, which meant that they appreciated Edmodo use for writing lessons (Table 3).

\section{Discussion}

Referring to the first research question about the students' overall opinions about using Edmodo, it is observed that the students held positive opinions (overall M: 4.69, see Table 1). This result supported and in line with the research results conducted on the perceptions of using Edmodo by Purnawarman, Susiliwati and Sundayana (2016), 
Kayacan and Razı (2017), Hamutoğlu and Kıyıcı (2017), Manowong (2016), Kongchan (2013) and Pop (2013).

The students seemed to favour collaborative writing as the mean value, 3.90, of item 26 suggests (Table 1). They appreciated Edmodo as social platform as the qualitative results of item 33 indicated with a mean value of 4.21 (Table 1). The students found Edmodo enjoyable. Furthermore, it was observed that the students were content with using Edmodo as supported by the quantitative results of item 14 suggested. Similarly, the participants in Kongchan (2013) favoured working collaboratively via Edmodo and Google Docs in real time, which is also supported by the following qualitative data of the present study:

Using Edmodo and Google Docs as a group, we both saw our own mistakes and learned from our friends' mistakes. I think it speeded up our learning this way (Interview Records, S1).

It is a very useful application in terms of seeing our grammar mistakes, and when we use Google Docs simultaneously, it is a useful application to correct and learn the mistakes of our friends, and to see and correct our own mistakes, too (Interview Records, S4).

On the other hand, the students considered using Edmodo interactively helped develop their writing skill. The students agreed on the item 34 (M: 4.05; SD: 0.93) that they both learnt from their mistakes and their friends' mistakes, which was also supported by the qualitative data. This finding is also in line with the research results conducted by Kayacan and Raz1 (2017), whose participants explained that they were able to learn from their friends' mistakes. Next, the perceptions of students supported the efficiency of immediate feedback like the participants of Purnawarman, Susiliwati and Sundayana (2016). Next, the students' agreements on the items 34, 31 and 21 (Table 2) strengthen the hypothesis that the social norms can be useful while teaching EFL writing.

Another function appreciated by the students is the e-portfolio function of Edmodo. The students seemed to appreciate that their work is available whenever they need it. They also seemed to like the facility that they can compare and contrast the quality of their work thanks to e-portfolio function of Edmodo (item 18, Table 2). These results were parallel to the study of Pop (2013). In the study, the students favoured Edmodo by agreeing that it is a user-friendly application which allowed them to engage interactive games and they easily uploaded their assignments. Likewise, the participants in Purnawarman, Susiliwati and Sundayana (2016) found Edmodo easy to use, and fun and attractive. Besides, the participants stated that Edmodo gave them limitless access. Similarly, the participants in the study of Hamutoğlu and Kıyıcı (2017) appreciated Edmodo because they were able to reach their course materials whenever they needed.

Our data revealed that the students remark Edmodo as a useful, social platform enabling easy interaction, collaboration and cooperation to exchange their opinions, suggestions, and helping each other to complete various tasks (mean: 4.06, Table 3), which was a comparable result to Purnawarman, Susiliwati and Sundayana (2016), whose participants stated that Edmodo provided them easy interaction for group discussions. Based on the students' responses to the items on the questionnaire and qualitative results of the semi structured interview, it can be stated that Edmodo enables them a practical way 
to interact for their writing tasks. Therefore, they can follow the stages of collaborative works which are explained by Harrasim (2012).

One concern on planning to use Edmodo and Google Docs for collaborative writing works for the study and class use was the possibility of reluctance of some students because of their introvert characteristics. They may not benefit from the activities carried out collaboratively, and the social aspects of learning may not suit to those students in question. The results, however, revealed that those students were few in number $(N: 3.8)$ as the qualitative results of item 30 and 16 suggested (Table 1). Although the students may have been considered as 'digital natives' nowadays, they might have had problems using Edmodo, which was another concern. Yet, the results showed that they did not have any problems (item 7, Table 1). Still, in order to include all the students in the activities, those students, though very few in number, should be further interviewed to find a solution.

\section{Conclusion}

The findings of this study suggest that Edmodo may provide a good virtual platform with its all functions enabling easy and effective interaction and communication. Writing would be more communicative and interactive idea both in and out of the classroom when Web 2.00 tools such as Edmodo was applied. Therefore, learning would become social in a unity in terms of Vygotsky's social cultural learning theory, and thus, writing activities would not take place in isolation. In addition, the students' high interest on technology and their computer literacy would be benefitted in writing classes. Naturally, in this study, the students followed three stages suggested in OCL theory (Harrasim, 2012). Accordingly, the students first discussed the writing topic by using discussion functions of online tools, and then, knowledge construction took place during the writing stage, where they collaborated. In the last stage, they benefitted either from teacher's or peers' feedback. It could be concluded that Edmodo may provide an interactive virtual learning platform that enables scaffolding in the frame of social learning suggested by Vygotsky; and contribute to development of learners' writing skill as it facilitates interaction and communication; increase students' interaction and communication. It is easy to use web tools which lead to creating an e-portfolio in the end. Google Docs combination with Edmodo may help form communicative and interactive writing tasks. The students liked and appreciated Edmodo in this study, and they benefitted from interaction and communication facilities of Edmodo for their ESL writing classes. Such Web 2.00 tools as wikis, blogs, Google Docs and Edmodo are highly recommended for classroom use.

This study is limited to the perceptions of the students towards the use of Edmodo. Future research may consider the quality of collaborative writing tasks in experimental designs. Group dynamics and students' interaction preferences may be the focus of future research as well. Additionally, the use of Edmodo for the other language skills can be researched. 


\section{References}

Brown, H.D., \& Lee, H. (2015). Teaching by principles: An interactive approach to language pedagogy (4th Edition). Pearson.

Creswell, J. W., \& Plano Clark, V. L. (2011). Designing and conducting mixed methods research (2nd Ed.). Sage.

Elola, I., \& Oskoz, A. (2010). Collaborative writing: fostering foreign language and writing conventions development. Language Learning \& Technology, 14(3), 51-71. https://eric.ed.gov/?id=EJ907767

Graham, S. \& Sandmel, K. (2011). The Process writing approach: A meta-analysis. The Journal of Educational Research, 104(6), 396-407. https://doi.org/10.1080/00220671.2010.488703

Hamutoğlu, N. B. \&Kıyıcı, M. (2017). Bir eğitsel sosyal ağ olarak Edmodo'nun yükseköğretimde kullanımına yönelik öğrenci görüşlerinin incelenmesi [An Exploration of University Students' Views Regarding the Use of Edmodo as an Educational Social Network]. Trakya Üniversitesi Ë̆itim Fakültesi Dergisi, 7(2), 322-343. https://doi.org/10.24315/trkefd.290573

Harasim, L. (2012) Learning theory and online technologies. Routledge.

Karpati, A. (2009). Web 2 technologies for net native language learners: A "social CALL." ReCALL, 21(2), 139-156. https://eric.ed.gov/?id=EJ841806

Kayacan, A., \& Razi, S. (2017). Digital self-review and anonymous peer feedback in Turkish high school EFL writing. Journal of Language and Linguistic Studies, 13(2), 561-577. https://dergipark.org.tr/tr/download/article-file/440790

Klimova, B. F. (2014). Approaches to the teaching of writing skills. Procedia-Social and Behavioral Sciences (112), 147-151. https://doi.org/10.1016/j.sbspro.2014.01.1149

Kongchan, C. (2013). How Edmodo and Google Docs can change traditional classrooms. The European Conference on Language Learning 2013 Official Conference Proceedings 2013. http://iafor.info/archives/offprints/ecll2013offprints/ECLL2013_0442.pdf.

Manowong, S. (2016). Undergraduate Students' Perceptions of Edmodo as a Supplementary Learning Tool in an EFL classroom. Silpakorn University Journal Social Sciences, Humanities and Arts Vol. 16(2), 137-161. http://www.thaiscience.info/journals/Article/SUIJ/10984811.pdf

OECD. (2013). Trends shaping education 2013. OECD Publishing.

OECD. (2015). Students, computers and learning - making the connection. OECD Publishing.

Olshtain, E. (2000). Functional tasks for mastering the mechanics of writing and going just beyond. In M. Celce-Murcia (Ed.), Teaching English as a second or foreign language (pp. 207232). Heinle and Heinle.

Pop, A. (2013). Edmodo e-portfolios in EFL - A case study. The 8th International Conference on Virtual Learning ICVL 2013. http://c3.icvl.eu/disc/2013/icvl/documente/pdf/intel/ ICVL_IntelEducation_paper8.pdf

Prensky, M. (2001). Digital natives, digital immigrants, part 1, On the Horizon, 9(5), 1-6. https:// doi.org/10.1108/10748120110424816

Raimes, A. (1983). Techniques in teaching writing. New York: Oxford University Press. 
Purnawarman, P., Susilawati, \&Sundayana, W. (2016). The use of Edmodo in teaching writing in a blended learning setting. Indonesian Journal of Applied Linguistics, 5 (2), 242- 252. https://doi.org/10.17509/ijal.v5i2.1348

Seyyedrezaie, Z. S., Ghonsooly, B., Shahriari, H., \& Fatemi, H. H. (2016). Mixed methods analysis of the effect of Google Docs environment on EFL Learners' writing performance and causal attributions for success and failure. Turkish Online Journal of Distance Education (TOJDE), (17), 90-110. http://dergipark.ulakbim.gov.tr/tojde/article/viewFile/ $5000196874 / 5000170473$

Stacey, E. (1999). Collaborative learning in an online environment. Journal of Distance Education, 14(2), 14-33. http://www.ijede.ca/index.php/jde/article/view/154/379

Storch, N. (2005). Collaborative writing: Product, process, and students' reflections. Journal of Second Language Writing, 14(3), 153-173. https://doi.org/10.1016/j.jslw.2005.05.002

Trust, T. (2017). Motivation, empowerment, and innovation: Teachers' beliefs about how participating in the Edmodo math subject community shapes teaching and learning. Journal of Research on Technology in Education, 49(1-2), 16-30. http://10.1080/15391523.2017.1291317

Tsiakyroudi, M. (2018). Exploring the effectiveness of Edmodo on Greek EFL B1 learners' motivation to write. Research Papers in Language Teaching and Learning, 9(1), 96-112. https://rpltl.eap.gr/images/2018/09-01-096-Tsiakyroudi.pdf

Vygotsky, L. S. (1978). Mind in society. The development of higher psychological processes. Harvard University Press.

Woodrich, M., \& Fan, Y. (2017). Google Docs as a tool for collaborative writing in the middle school classroom. Journal of Information Technology Education: Research, 16, 391-410. http://jite.org/documents/Vol16/JITEv16ResearchP391-410Woodrich3331.pdf

Wu, H. J., \& Wu, P. L. (2011). Learners' perceptions on the use of blogs for EFL learning. USChina Education Review, 1(3), 323-330. https://eric.ed.gov/?id=ED524902 